Elsevier required licence: $(c)<2018>$. This manuscript version is made available under the CC-BY-NC-ND 4.0 license http://creativecommons.org/licenses/by-nc-nd/4.0/ 


\title{
Improvement of bioavailable carbon source and microbial structure toward enhanced nitrate removal by Tubifex tubifex
}

\author{
Yan Kang ${ }^{\mathrm{a}}$, Jian Zhang ${ }^{\mathrm{a}, *}$, Bo Li ${ }^{\mathrm{b}}$, Yijin Zhang ${ }^{\mathrm{b}}$, Huiling Sun ${ }^{\mathrm{b}}$, Huu Hao Ngo ${ }^{\mathrm{c}, *}$, Wenshan Guo ${ }^{\mathrm{c}}$, \\ Huijun Xie ${ }^{\mathrm{d}}$, Zhen $\mathrm{Hu}^{\mathrm{a}}$, Congcong Zhao ${ }^{\mathrm{e}}$ \\ ${ }^{a}$ Shandong Key Laboratory of Water Pollution Control and Resource Reuse, School of Environmental \\ Science and Engineering, Shandong University, Jinan, Shandong 250100, China \\ ${ }^{b}$ Shandong Academy of Environmental Science, Jinan, Shandong 250013, China \\ ${ }^{c}$ School of Civil and Environmental Engineering, University of Technology Sydney, Broadway, NSW \\ 2007, Australia \\ ${ }^{d}$ Environmental Research Institute, Shandong University, Jinan 250100, China \\ ${ }^{e}$ College of Geography and Environment, Collaborative Innovation Center of Human-Nature and Green \\ Development in Universities of Shandong, Shandong Normal \\ University, Jinan 250014, China \\ *Corresponding author.E-mail: zhangjian00@sdu.edu.cn (J.Zhang),HuuHao.Ngo@uts.edu.au (H.Hao \\ Ngo).
}

\begin{abstract}
The research provides new insights into how T. tubifex affects microbe-available organic carbon transformation, microbial community, and related inorganic nitrogen transformation. With different $T$. tubifex densities under enriched $\mathrm{NO}_{3}-\mathrm{N}$ concentration with different $\mathrm{C} / \mathrm{N}$ ratio, the groups with low and high T. tubifex abundance had $17.1 \%$ and $27.2 \%$ higher TOC concentrations compared to control group under $\mathrm{C} / \mathrm{N}$ ratio of 3.0 and 2.0, respectively. According to the $\mathrm{OC}$ characteristics analyzed by GC-MS and EEM, the group with T. tubifex contained higher dissolved organic carbon (DOC) content and short-chain compounds. As the $\mathrm{NO}_{3}-\mathrm{N}$ concentration increased and $\mathrm{C} / \mathrm{N}$ ratio decreased, the proportions of carboxylic acid derivatives (methyl acetate), sulfurcontaining compounds, humic-like products and the emission of $\mathrm{CO}_{2}$ were enhanced with $T$. tubifex, which could be utilized by denitrifiers directly. The OC degradation was highly correlated with the effect of T. tubifex on microbial community and nutrient removal. The T. tubifex can increase OC transformed into sediment and change the microbial community similarity to that in their digestive system. According to the principal component analysis (PCA), the improved proportions of OC that available for microbes and altered microbial community with $T$. tubifex could enhance denitrification, which experienced a $21 \%$ higher denitrifiers and threefold increased $\mathrm{NO}_{3}-\mathrm{N}$ removal efficiency than that in control group.
\end{abstract}

Keywords: $T$. tubifex, Denitrifier-available organic carbon, Denitrifiers, ${ }^{15} \mathrm{~N}$ labeling experiment

\section{Introduction}

Water-sediment interface is a combined aerobic and anaerobic zone, where microbial processes and burrowing invertebrates are preferentially considered [1]. Tubifex tubifex (T. tubifex) is a typical micro-benthic invertebrates in freshwater ecosystems [2]. To date, most of previous studies have specifically reported that $T$. tubifex stimulates benthic nitrification and denitrification in the aerobic-anaerobic transition zone of the sediment [3], [4]. Apart from nitrogen $(\mathrm{N})$ removal, the 
worms can also improve the aeration of sediment and further improve physical-chemical properties of soil by mixing with organic material [5]. T. tubifex is known to be relatively important for enhancing carbon mineralization and cycling in freshwater systems [6]. However, there is a lack of studies that characterize the impact of $T$. tubifex on the relationship between organic carbon transformation and nitrate $\left(\mathrm{NO}_{3}-\mathrm{N}\right)$ removal.

Inorganic $\mathrm{N}$ loss, especially in the form of $\mathrm{NO}_{3}-\mathrm{N}$, is a critical issue and major limiting factor for nitrogenous control in effluent from traditional wastewater treatment plant (WWTP) [7]. Transformation of $\mathrm{NO}_{3}-\mathrm{N}$ to other inorganic $\mathrm{N}$ through microbial process, such as denitrification $\left(\mathrm{NO}_{3}-\mathrm{N}\right.$ to $\mathrm{N}_{2}$ ) and dissimilatory nitrate reduction to ammonium (DNRA, transformed to nitrous oxide $\left(\mathrm{N}_{2} \mathrm{O}\right)$ or ammonium $\left.\left(\mathrm{NH}_{4}-\mathrm{N}\right)\right)$, is a potential way for $\mathrm{NO}_{3}-\mathrm{N}$ removal [8], [9]. The $\mathrm{C} / \mathrm{N}$ ratio significantly influences these microbial processes, especially influence denitrification by improving the growth of denitrifying bacteria [10]. Higher organic carbon with an anoxic condition was the most important factor stimulates heterotrophic denitrification process [11]. Normally, aquatic ecosystems feed with secondary effluent from municipal WWTP often encounter the deficiency of available carbon sources, which further limits $\mathrm{NO}_{3}-\mathrm{N}$ removal through denitrification [12], [13]. The main reason is that most of organic matters accumulated in aquatic systems is recalcitrant and difficult to biodegrade [14]. Thus, they are not readily utilized by microbes. To solve this problem, some organic materials such as glucose or wheat straw, was added as extra carbon source but may cause problems like overdosing and high organic carbon pollution in effluent [15]. As the requirement of removing $\mathrm{NO}_{3}-\mathrm{N}$ in developing strategies for eutrophication prevention, increasing attention should been given to the microbial available carbon sources for denitrification.

The biological characteristics of carbon source was important for $\mathrm{NO}_{3}-\mathrm{N}$ removal. The higher availability of organic carbon could augment soil microbial activity [16], [17], [18]. So, the better strategy to solve the lack of carbon source is to generate partially products that can be readily utilized by microbes [19]. For example, the low-molecular-weight and short-chain aliphatic hydrocarbon, as well as sulfur compounds were much easier for microbial utilization. The type of organic carbon determines whether they can be easily utilized by microbes, while some related microbes was also importantly for organic carbon degradation. Biodegradation by microbes is the ultimate fate of majority organic carbon for utilization by breaking down organisms, either in aerobic or anaerobic conditions [20], [21]. And microbial decomposition is also one of the major natural processes that alter organic carbon characteristics and reactivity. Previous studies has revealed the significance of functional carbon-degrading microorganisms to organic carbon treatment and transformation [22]. The T. tubifex has been known to have significant influence on $\mathrm{NO}_{3}-\mathrm{N}$ removal. Its activity also changed microbial community and organic carbon cultures in aquatic environment, which were important factors for denitrification. So, understanding the effect of $T$. tubifex on interactions between biodegradable organic carbon transformation and the microbial component of the aquatic ecosystem and their effect on denitrification remains a key factor for $\mathrm{NO}_{3}-\mathrm{N}$ removal.

This is the first study to provide comprehensive information on how T. tubifex influence the degradation of organic carbon and related microbes that mitigate excessive $\mathrm{NO}_{3}-\mathrm{N}$ loads in aquatic ecosystems. The experiments were performed with different T. tubifex densities under enriched 
$\mathrm{NO}_{3}-\mathrm{N}$ concentration with different $\mathrm{C} / \mathrm{N}$ ratios. To quantitatively understand the underlying mechanisms, the following two specific objectives were pursued: 1) to evaluate different forms of organic carbon transformed with T. tubifex; 2) to quantify microbial communities in T. tubifex and sediment, in order to determine the link between organic carbon biodegradation, microbial processes and $\mathrm{NO}_{3}-\mathrm{N}$ removal under the influence of T. tubifex.

\section{Materials and methods}

\subsection{Experimental set-up, start-up and operation strategy}

The experimental microcosms were established in laboratory in Shandong University. A total of nine $2500 \mathrm{~mL}$ glass beakers were used for the experiments. Each microcosm was filled with sediment at $5 \mathrm{~cm}$ depth in the bottom. $2 \mathrm{~L}$ synthetic wastewater were added to stimulate the polluted aquatic environment (the profile of microcosms were shown in Supplementary materials), with the water depth of $15 \mathrm{~cm}$. Freshwater sediment used in this study were collected from the Zhaoniu River constructed wetland (CW) in Qihe, and T. tubifex were got in a local market in Jinan, both in Shandong, China. Each microcosm was equipped with an airtight cork at the top which contained two drilled holes. Each hole contained a glass tube and a valve, which were used for gas and wastewater collection, respectively. For gas collection, the top of each microcosm was corked to keep airtight. After collection, the experimental microcosms were left uncapped to keep aeration for T. tubifex. The nine microcosms were set up with three different treatments $(\mathrm{n}=3$ per treatment): (1) low abundance of T. tubifex (3 g per microcosm, namely LA group); (2) high abundance of $T$. tubifex (6 g per microcosm, namely HA group); (3) parallel experimental control under the same conditions but without T. tubifex (namely control group).

A laboratory-scale sequencing batch-operated procedure was adopted in this experiment. After each cycle, the wastewater was drained from the top of each glass beaker. Then filled with wastewater for the next cycle. To keep the T. tubifex alive and detect its effect on water purification, the influent wastewater to each experimental microcosm was stimulated the Class I (B) according to the Wastewater Discharge Standard (GB18918-2002) [23]. Artificial synthetic wastewater prepared from tap water containing sucrose, $\left(\mathrm{NH}_{4}\right)_{2} \mathrm{SO}_{4}$, and $\mathrm{KNO}_{3}$. To identify the different transformation pathways and influence mechanisms with increased $\mathrm{NO}_{3}-\mathrm{N}$ loading, the total research was divided into two phases according to the varying operational conditions (different $\mathrm{C} / \mathrm{N}$ ratio and $\mathrm{NO}_{3}-\mathrm{N}$ concentrations). The characteristics of the influent wastewater in each phase are described in Table 1. In Phase 1, the composition of synthetic wastewater were as follows $(\mathrm{mg} / \mathrm{L})$ : sucrose $51.3, \mathrm{KNO}_{3} 76.6$, and $\left(\mathrm{NH}_{4}\right)_{2} \mathrm{SO}_{4}$ 37.6. In phase 2, the dosage of sucrose and $\left(\mathrm{NH}_{4}\right)_{2} \mathrm{SO}_{4}$ were similar to that in Phase 1 , but the $\mathrm{KNO}_{3}$ increased to $140 \mathrm{mg} / \mathrm{L}$. The experiment lasted from December 2015 to April 2016. There were five and seven cycles for Phase 1 and 2 . The hydraulic retention times (HRTs) of each cycle were 6 days and 8 days for two phases, respectively. Before each phase, the experimental groups were stable for three cycles. The unstable cycles were not reflected in the figures.

\subsection{Isotope pairing technique (IPT) and $15 N$ tracer calculations}

To explore the denitrification and DNRA process with T. tubifex, the fractionation factor associated with $\mathrm{N}_{2} \mathrm{O}$ and $\mathrm{NH}_{4}-\mathrm{N}$ production from $\mathrm{NO}_{3}-\mathrm{N}$ were conducted in ${ }^{15} \mathrm{~N}$ labeling experiment [5], [18], 
[24]. Subsequently, (1) ${ }^{15}\left(\mathrm{NH}_{4}\right)_{2} \mathrm{SO}_{4}\left(99\right.$ atom \%) $+\mathrm{K}^{14} \mathrm{NO}_{3}$, and (2) ${ }^{14}\left(\mathrm{NH}_{4}\right)_{2} \mathrm{SO}_{4}+\mathrm{K}^{15} \mathrm{NO}_{3}(99$ atom \%) was added to each group to achieve concentrations similar to the input concentration of $\mathrm{NO}_{3}-\mathrm{N}$ and $\mathrm{NH}_{4}-\mathrm{N}$ in the second phase. After ${ }^{15} \mathrm{~N}$ was added, the microcosms were kept airtight until gas and water sampling conducted. Headspace gas and wastewater samples were obtained at the $144 \mathrm{~h}$ of experimental period (equilibrium time) and immediately analyzed to obtain the atom percentage and $\delta^{15} \mathrm{~N}$ values of $\mathrm{N}_{2} \mathrm{O}, \mathrm{N}_{2}$, and $\mathrm{NH}_{4}-\mathrm{N}$. ${ }^{15} \mathrm{~N}$ abundance measurements in $\mathrm{N}_{2} \mathrm{O}, \mathrm{N}_{2}$ and $\mathrm{NH}_{4}-\mathrm{N}$ was performed using Isoprime 100-EA (isotope ratio mass spectrometer), TracegasIsoprime 100 and Deha plus-Gasbench (elemental analyzer) in Environmental Stable Isotope Lab, Chinese Academy of Agricultural Sciences.

Table 1. Characteristics of the influent wastewater compositions during two experimental phases.

\begin{tabular}{lllllll}
\hline & COD (mg/L) & TOC $(\mathbf{m g} / \mathbf{L})$ & $\mathbf{N O}_{3}-\mathbf{N}(\mathbf{m g} / \mathbf{L})$ & $\mathbf{N H}_{4}-\mathbf{N}(\mathbf{m g} / \mathbf{L})$ & $\mathbf{T N}(\mathbf{m g} / \mathbf{L})$ & $\mathbf{C} / \mathbf{N}$ \\
\hline Phase 1 & \multirow{2}{*}{$60.00 \pm 3.24$} & $24.30 \pm 0.34$ & $12.00 \pm 0.00$ & & $20.45 \pm 1.22$ & $2.93 \pm 0.03$ \\
Phase 2 & & & $22.13 \pm 0.13$ & & $30.12 \pm 0.19$ & $1.99 \pm 0.02$ \\
\hline
\end{tabular}

\subsection{Analytical methods}

\subsubsection{Water qualities monitoring}

Water samples $(50 \mathrm{~mL})$ were collected with plastic syringes from the overlying wastewater every two days. The dissolved oxygen (DO) were tested in situ at the same time with a DO meter (HQ40d53LDO ${ }^{\mathrm{TM}}$, HACH, USA). Laboratory analysis was performed on the water samples for $\mathrm{NH}_{4}-\mathrm{N}, \mathrm{NO}_{3}-\mathrm{N}$, nitrite $\left(\mathrm{NO}_{2}-\mathrm{N}\right)$, total organic carbon (TOC) and chemical oxygen demand (COD) after filtering through a $0.45-\mu \mathrm{m}$ cellulose acetate membrane syringe filter. All the parameters mentioned above were determined according to standard methods [25].

\subsubsection{Sediment qualities monitoring}

The top $1 \mathrm{~cm}$ sediment with equal amounts in five individuals were collected and homogenized after each experimental period, because this is where the habitat for T. tubifex and where bacteria associated with the degradation of nutrients were most likely to be present. Sediment samples were dried at $-60{ }^{\circ} \mathrm{C}$ using a freezer dryer (Unicryo MC $2 \mathrm{~L}$ freeze dryer, Germany) for $36 \mathrm{~h}$, then sieved $(0.2 \mathrm{~mm})$ and stored at $-20^{\circ} \mathrm{C}$ for other analysis.

The dissolved organic matter (DOM) extracted from sediment in each group was well assessed in each Phase [4]. The amount of DOM released from sediment (expressed as DOC) and the UV absorption spectra were determined using a total organic carbon analyzer (Shimadzu, TOC-L, Japan) and a UV spectroscopy (Shimadzu, UV-1780, Japan). The fluoresce EEM spectra was created by a fluorescence spectrometer (F97 Pro, Lengguang Tech., China) and validated using parallel factor (PARAFAC) modelling conducted with MATLAB. Excitation $\left(\lambda_{\mathrm{EX}}\right)$ and emission $\left(\lambda_{\mathrm{EM}}\right)$ wavelength ranges were set from 200 to $550 \mathrm{~nm}$ and $250-550 \mathrm{~nm}$, with the scanning intervals and frequency with $5 \mathrm{~nm}$ and $1 \mathrm{~nm} \mathrm{~min}^{-1}$, respectively. Three main compounds were evaluated using the FRI technique as described by Wen et al. [26], including tyrosine-like contents (component 1), soluble microbial byproduct-like material (SMP, component 2) and humic acidlike compound (component 3 ). The calculated methods for other significant indices and parameters for DOM, such as humification index (HIX), Ultraviolet Visible (UV) absorbance at $254 \mathrm{~nm}$ (SUVA254), were detailed description in the Supplementary materials. 
The degradation by-product of the organic carbon storage in sediment samples was qualitative analyzed using a gas chromatography equipped with a mass spectrometer (GC-MS, GCMS-QP 2020, Shimadzu, Japan) according to the Chinese hazardous waste identification standard method (GB 5085.3-2007). The separation was carried out using an Rtx-5 MS column (Restek, $60 \mathrm{~m} \times 0.25 \mathrm{~mm}$ id; film thickness, $0.25 \mu \mathrm{m}), 30 \mathrm{~m} \times 0.25 \mathrm{~mm}$ i.d., containing $5 \%$ phenylmethylpolysiloxane with thickness of $0.25 \mu \mathrm{m}$. Pure helium gas $(99.995 \%)$ was used as the carrier gas with the flow rate of $2 \mathrm{~mL} / \mathrm{min}$. The mass spectrometer conditions were as follows: EI mode, ion source temperature of $230^{\circ} \mathrm{C}$, interface temperature of $280^{\circ} \mathrm{C}$, full scan mode. The injector and detector temperature were maintained at $280{ }^{\circ} \mathrm{C}$. Oven temperature was held at $40^{\circ} \mathrm{C}$ for 5 min and increased to $160{ }^{\circ} \mathrm{C}$ at a rate of $6{ }^{\circ} \mathrm{C} / \mathrm{min}$. Then, the oven was operated at $160{ }^{\circ} \mathrm{C}$ for $6 \mathrm{~min}$, and increased by the rate of $20^{\circ} \mathrm{C} / \mathrm{min}$ until $230^{\circ} \mathrm{C}$. For chemical identification of peaks, mass of fragments were accurate by searching against the MS spectral library (NIST11 library, http://www.nist.gov/srd/mslist.htm) with the match greater than 95\%. The retention time was applied to confirm the identification of carbon components in GC-MS analysis. The GC-MS analysis was performed in the Shandong academy of Environmental Science.

\subsubsection{Gases qualities monitoring}

The gas was sampled at time intervals of $1 \mathrm{~h}$ (5 times) for $\mathrm{N}_{2} \mathrm{O}$ and $\mathrm{CO}_{2}$ analysis with a gas-tight plastic syringe $(20 \mathrm{~mL})$ to establish a linear production. And the gases were collected every two days in each period. After collection, $\mathrm{CO}_{2}$, and $\mathrm{N}_{2} \mathrm{O}$ were analyzed by a gas chromatograph (GC7890B, Agilent). The linear increase of these gas concentrations during the hour was used to calculate the rate of $\mathrm{N}_{2} \mathrm{O}$ and $\mathrm{CO}_{2}$ emission per specimen. We describe the gases emission fluxes calculated methods in Supplementary materials.

\subsection{Sample collection, DNA extraction, PCR amplification, sequencing and data analysis}

Before microbial analysis, the T. tubifex was conducted with 5 days starvation to allow full gut depuration. Then, the T. tubifex was washed with deionized water, and dried under $-60{ }^{\circ} \mathrm{C}$ for $48 \mathrm{~h}$. The DNA was extracted from the sediment and T. tubifex samples using PowerSand DNA Kits (MOBIO PowerSand ${ }^{\mathrm{TM}}$ DNA Isolation Kit). Because the individual of T. tubifex was too small to separate their digestive system, and the microbes was mainly existed in their digestive system after washing, the microbial analysis of T. tubifex could represent their gut microenvironment. Highthroughput sequencing of the V4-V5 region of the $16 \mathrm{~S}$ ribosomal ribonucleic acid (rRNA) gene was performed on the Miseq (Illumina) platform in the Novogene Co., LTD (Beijing, China). More details of Illumina high-throughput sequencing assays were reported in the previous research [4].

\subsection{Sample collection, DNA extraction, PCR amplification, sequencing and data analysis}

All measurements were performed in triplicate with the results expressed as mean \pm standard deviation. The program SPSS 19.0 (SPSS, Chicago, USA) was used to perform all the statistical analyses, and an analysis of variance (ANOVA) was used to test the significance different of results. The results were considered to be statistically significant when $p<0.05$. Standard deviations of three replicates were indicated by error bars. Principle component analysis (PCA) was conducted using Canoco 5.0 (Microcomputer Power, USA) to examine the effect of T. tubifex on nutrient 
removal and microbial community as well as discovering the correlations between each environmental factors and functional microbes.

\section{Results and discussion}

\subsection{Treatment performance of $N$ removal}

The treatment performance on $\mathrm{N}$ removal in each group during the experimental period is shown in Fig. 1. Regarding the outflow $\mathrm{TN}$ pollutants, inorganic $\mathrm{N}$ in control group was presented predominantly in the form of $\mathrm{NO}_{3}-\mathrm{N}$. As shown in Fig. $1 \mathrm{~A}-\mathrm{C}$, the $\mathrm{NO}_{3}-\mathrm{N}$ removal efficiencies of LA and HA groups were up to $100 \%$, which were twofold and threefold higher than control group in phases 1 and 2, respectively. Although $\mathrm{NH}_{4}-\mathrm{N}$ showed a little lower removal efficiencies in the absence of T. tubifex such as HA group in Phase 2 (Fig. 1B), better TN purification with T. tubifex was still observed primarily attributed to their excellent $\mathrm{NO}_{3}-\mathrm{N}$ removal capacity, which was consistent with previous research [4]. $\mathrm{NO}_{3}-\mathrm{N}$ consumption and simultaneous $\mathrm{N}_{2} \mathrm{O}$ production were measured in the experiment. As showed in Fig. 1D, the production of $\mathrm{N}_{2} \mathrm{O}$ from the groups with $T$. tubifex were higher than that of control group. The $\mathrm{N}_{2} \mathrm{O}$ emission rates was higher in Phase 2 than those in Phase 1, and the LA group achieved the highest $\mathrm{N}_{2} \mathrm{O}$ emission rate. In general, the complete $\mathrm{NO}_{3}-\mathrm{N}$ reduction to $\mathrm{N}_{2}$ was enabled when the $\mathrm{C} / \mathrm{N}$ ratio ranged from 3.0 to 6.0 , which was higher than the $\mathrm{C} / \mathrm{N}$ ratio in our experiment [11]. Thus, the $\mathrm{N}_{2} \mathrm{O}$ emission as an intermediate that could reflect the improved denitrification process with T. tubifex.

(A)

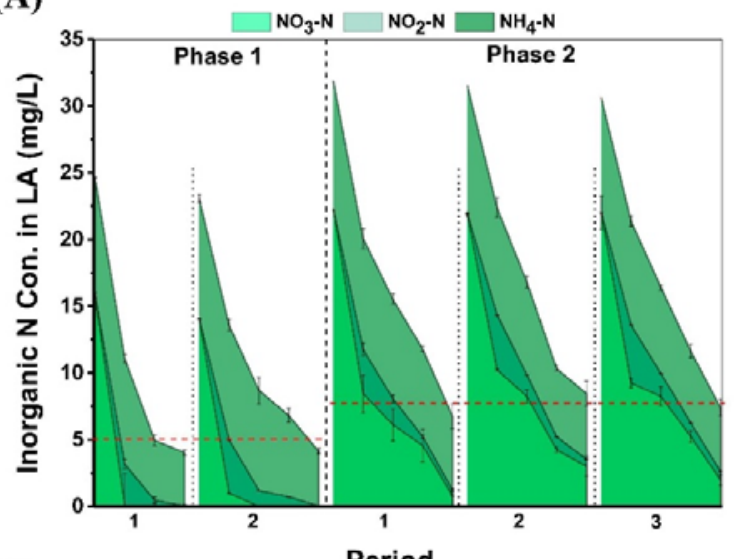

(C)

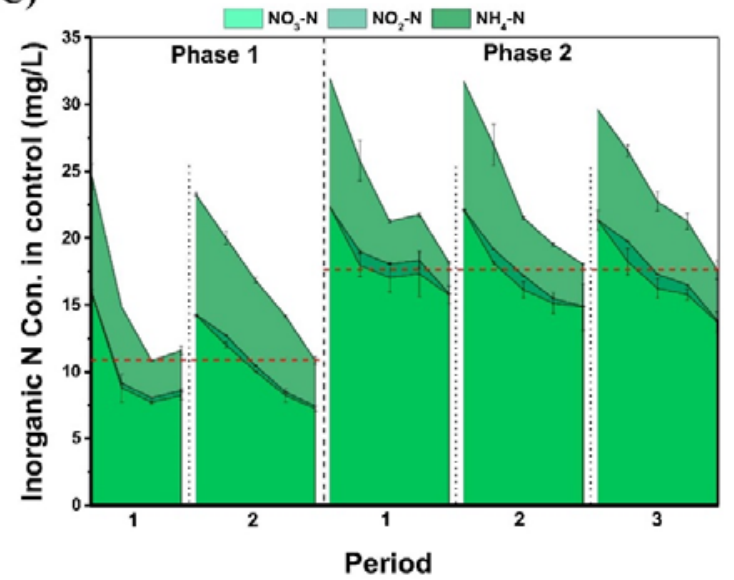

(B)

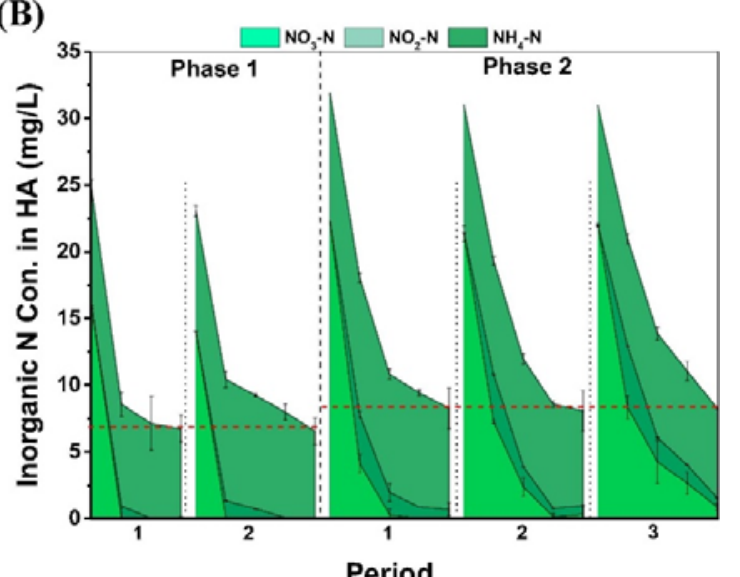

(D)

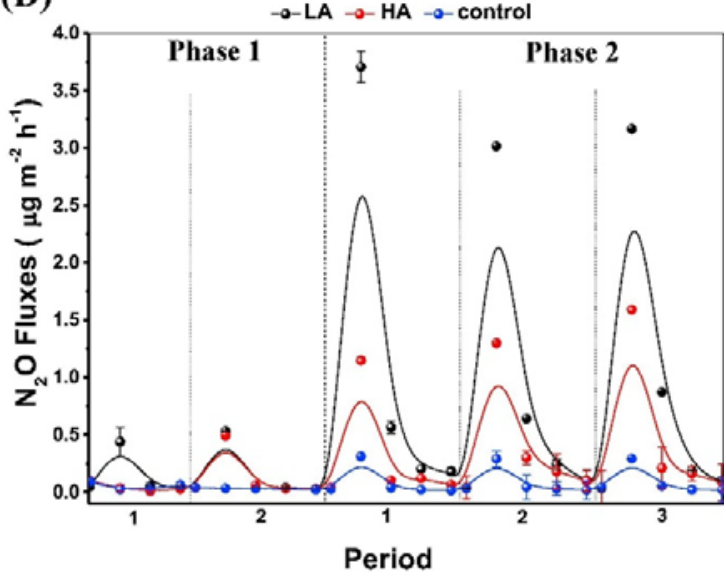

Fig. 1 The changes of $\mathrm{NO}_{3}-\mathrm{N}, \mathrm{NH}_{4}-\mathrm{N}$, and $\mathrm{NO}_{2}-\mathrm{N}$ in $\mathrm{LA}(\mathrm{A}), \mathrm{HA}(\mathrm{B})$ and control (C) group, and $\mathrm{N}_{2} \mathrm{O}$ emission fluxes in each group (D). 
The enhanced denitrification and DNRA processes with T. tubifex were confirmed based on the results for ${ }^{15} \mathrm{~N}$ labeling experiment. In ${ }^{15} \mathrm{NH}_{4}-\mathrm{N}$ and ${ }^{14} \mathrm{NO}_{3}-\mathrm{N}$ added experiment, the $\delta^{15} \mathrm{~N}$ of $\mathrm{N}_{2} \mathrm{O}$ produced by ${ }^{15} \mathrm{NH}_{4}-\mathrm{N}$ oxidation were lower in LA and HA. Considering the $\mathrm{N}_{2} \mathrm{O}$ concentrations for each group, it can be calculated that, only $\left(3.20 \times 10^{-3}\right) \% \mathrm{NH}_{4}-\mathrm{N}$ were oxidized to $\mathrm{N}_{2} \mathrm{O}$ in LA and HA groups. In ${ }^{15} \mathrm{NO}_{3}-\mathrm{N}$ and ${ }^{14} \mathrm{NH}_{4}-\mathrm{N}$ added experiment, LA has the highest ${ }^{15} \mathrm{~N}_{2} \mathrm{O}$, consistent with the highest $\mathrm{N}_{2} \mathrm{O}$ emission rate in LA group. According to the results, 107.02, 84.69, and $36.93 \mathrm{ppm}{ }^{15} \mathrm{~N}_{2} \mathrm{O}$ were detected in LA, HA and control group, respectively. And about $0.18 \%$, $0.17 \%$, and $0.05 \%{ }^{15} \mathrm{NO}_{3}-\mathrm{N}$ were reduced to ${ }^{15} \mathrm{~N}_{2} \mathrm{O}$ in LA, HA and control groups, respectively. As the final product of denitrification process, the $\delta$ values of ${ }^{15} \mathrm{~N}_{2}$ from $\mathrm{K}^{15} \mathrm{NO}_{3}$ in LA, HA, and control group were $116.22 \%, 117.36 \%$ and $80.38 \%$, respectively. On the basis of percentage value, it can be concluded that $\mathrm{NO}_{3}-\mathrm{N}$ has a higher contribution to $\mathrm{N}_{2} \mathrm{O}$ and $\mathrm{N}_{2}$ production with $T$. tubifex addition [27]. The contribution of DNRA to $\mathrm{NH}_{4}-\mathrm{N}$ accumulation with T. tubifex was investigated by incubating samples amended with ${ }^{14} \mathrm{NH}_{4}-\mathrm{N}$ and ${ }^{15} \mathrm{NO}_{3}-\mathrm{N}$. It can be calculated that, $6.38 \%$, $8.44 \%$, and $2.27 \% \mathrm{NH}_{4}-\mathrm{N}$ was transformed from $\mathrm{NO}_{3}-\mathrm{N}$, about $1.32 \%, 1.93 \%$ and $0.75 \%$ of ${ }^{15} \mathrm{NO}_{3}-$ $\mathrm{N}$ reduced to ${ }^{15} \mathrm{NH}_{4}-\mathrm{N}$ through DNRA process in LA, HA and control group, respectively. Thus, the higher $\mathrm{NH}_{4}-\mathrm{N}$ accumulation was partly attributed to $\mathrm{NO}_{3}-\mathrm{N}$ transformation with T. tubifex.

\subsection{Organic carbon removal}

\subsubsection{Organic carbon characteristics in wastewater}

A source of labile carbon source is an important electron donor to drive immobilization processes, especially in elevating $\mathrm{N}$ deposition [28]. Denitrification processes are generally favored when $\mathrm{O}_{2}$ consumption and ample organic carbon is available [29]. The performance of TOC and $\mathrm{CO}_{2}$ in each microcosm were well studied (Fig. 2). The highest removal efficiency of TOC in each group was detected in the first two days during each period, then decreased steady. TOC was more rapidly biodegraded in control group. The effluent TOC concentrations were in the order of $\mathrm{HA}>\mathrm{LA}>$ control, with the range of $5.00-9.00 \mathrm{mg} / \mathrm{L}$ in Phase 1 , and $4.00-7.00 \mathrm{mg} / \mathrm{L}$ in Phase 2. Lower TOC concentration in Phase 2 was mainly due to the higher organic carbon demanded for $\mathrm{NO}_{3}-\mathrm{N}$ removal. Thus, $T$. tubifex could use little carbon source to achieve higher $\mathrm{NO}_{3}-\mathrm{N}$ removal efficiency. The biodegradation of organic carbon by microbes and mineralization, as well as the respiration of T. tubifex contributed to $\mathrm{CO}_{2}$ release in LA and HA groups. Coupled with TOC concentration, there was an increased $\mathrm{CO}_{2}$ emission with T. tubifex, especially in Phase 2 (Fig. 2B). In the whole experiment, $\mathrm{HA}$ group always had highest $\mathrm{CO}_{2}$ emission rate, and followed by LA group, indicating the effect of T. tubifex on C cycling. Although the TOC removal efficiencies in LA and HA group were only $5.93 \%$ and $11.19 \%, 5.14 \%$ and $8.98 \%$ lower compared to control group, the $\mathrm{NO}_{3}-\mathrm{N}$ removal efficiencies in LA and HA groups were twofold and threefold higher than those in control group. This means that the increased denitrification might be partially due to the transformation of bioavailable organic carbon rather than the residual carbon source.

\subsubsection{Organic carbon characteristics in wastewater}

T. tubifex mainly habitat and excrete in sediment. So the different organic carbon forms was well studied in sediment. The quantity of organic carbon in the sediment of each group was presented in Fig. 3 and Table 2. Similar to the TOC results in wastewater, the TOC contents in sediment showed the same tendency of HA $>$ LA $>$ control. It has been known that the TOC content, including much of the soluble organics as DOC in sediment, was bioavailable and easier to be degraded [21], [30]. The DOC is derived from the oxidation of soil organic matter and is essential 
for determining sources of labile carbon and higher organic carbon solubility. Thus, the DOC cultures were also studied. LA and HA groups resulted in a higher proportions of DOC, which were $18.4 \%$ and $33.1 \%$ higher than that from control group after Phase 1. DOC concentrations for three groups experienced a decline after the experiment in Phase 2, which was approximately half of those in Phase 1.
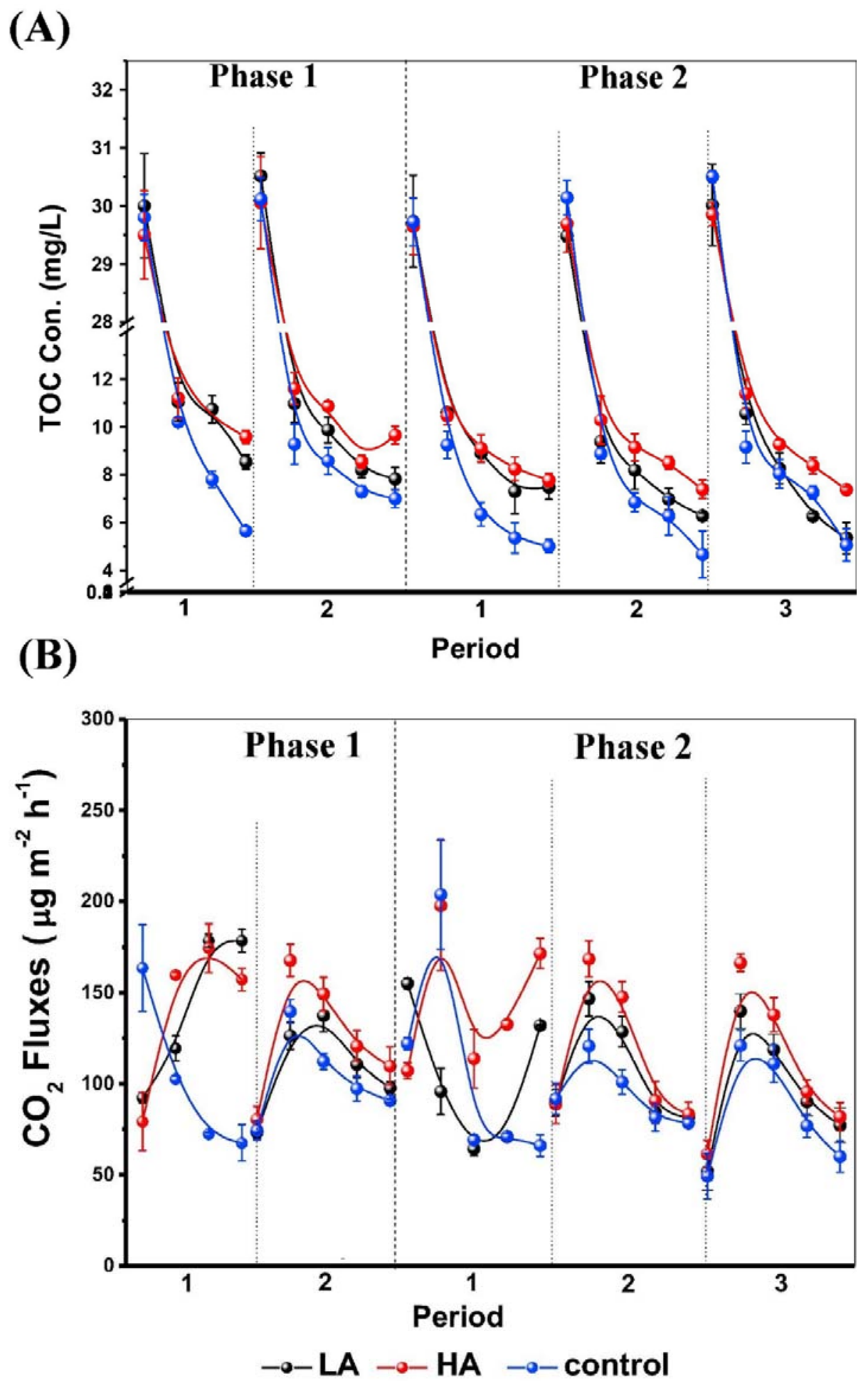

Fig. 2 Dynamics of TOC (A) and $\mathrm{CO}_{2}$ emission fluxes (B) in different treatments. 

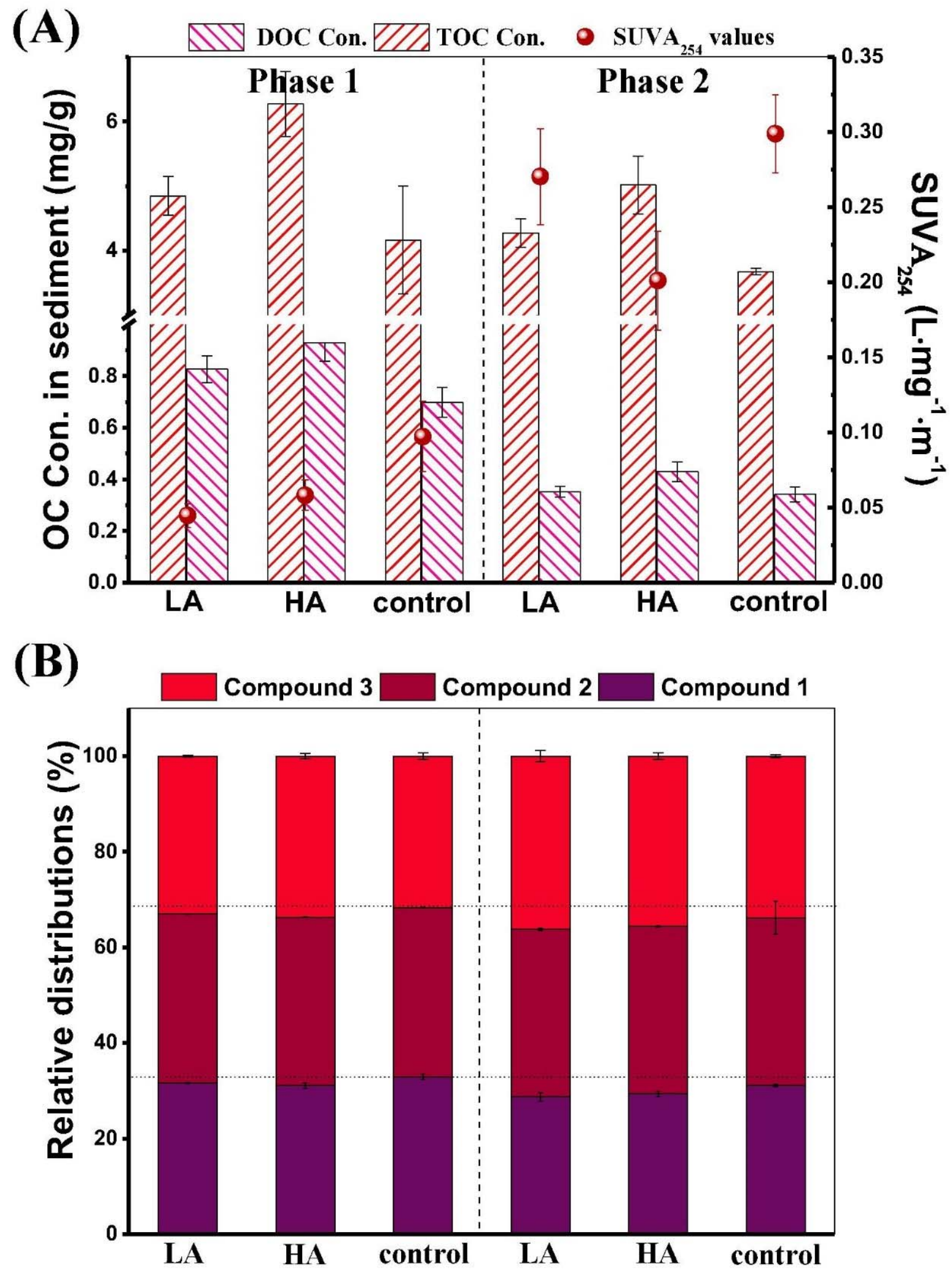

Fig. 3 Dynamics of DOM in sediment during two phases incubation: (A) TOC, DOC contents and average sediment solution SUVA254 values in various groups; (B) relative distributions of three components in DOM calculated by PARAFAC modeling. 
The lowest DOC concentration was still obtained in control group, which was $2.9 \%$ and $25.6 \%$ lower compared to LA and HA group. T. tubifex can uptake and exchange the flow of pollutants through two main routes: 1) passive uptake the compounds dissolved in water through the epidermis and transformed these compounds into sediment (indirectly affect), 2) then ingested pollutants passes through the digestive track after ingestion of soil particles, water, and food (directly affect) [31]. T. tubifex is an upward-conveyor, thus feeding on sediment and ejecting faecal pellets at the water-sediment interface. The indirectly effect of $T$. tubifex also facilitate and increase the contact between contaminant and soil microorganisms [32], the top-down behavior including the predation and excretion activity from $T$. tubifex has a stimulatory effect on increasing the turnover of nutrients (including $\mathrm{C}$ and $\mathrm{N}$ ) into superficial sediment [22]. The high DOC concentration is an energy source for microbial metabolism [33]. Among them, smaller organic carbon compounds are generally degraded by microbes much easier, because it was correlated with the acid functional group density and volatile matter contents [31]. Negatively correlated with the DOC concentrations, the SUVA 254 values in the control group was highest, which was 2 and 1.5 times higher than that in LA and HA group in Phase 1. After the experiment in Phase 2, the SUVA $_{254}$ value in the control group was increased by a factor of 3, and was still $10.5 \%$ and $48.6 \%$ higher than that in LA and HA. The enhanced SUVA 254 value was attributed to the microbial transformation of labile compounds into refractory organic carbons [34], reflecting the difficulty of organic carbon microbial utilization in control group. The component distributions in different groups are shown in Fig. 3B. The control group, in general, showed no change in fluorescence intensities for all components in two phases, while the variability of DOM with T. tubifex remained more or less altered in fluorescence. The DOM composition from LA and HA group was changed with a slight removal of Compound 1 and increased proportion of Compound 3. The better quality of humic-like organic carbon with T. tubifex presented more biodegraded DOM and much easier for microbial use [25], [35]. The results indicated that organic components were transformed during the denitrification process. Furthermore, the higher humic-acid like compounds with T. tubifex could improve soil fertility and reduce the need for external addition of large amounts of fertilizers [26], [32], [33]. This was coincidence with the levels of HIX. Mean HIX values were relatively higher with T. tubifex, which also indicated the higher degree of humification of soil DOM with $T$. tubifex. Other indexes, such as BIX, $\mathrm{S}_{\mathrm{R}}$ showed no difference between each group.

Table 2. Fluorescence parameters of major index values calculated by PARAFAC modeling in sediments from different treatment.

\begin{tabular}{|c|c|c|c|c|c|c|c|c|}
\hline Time & Group & HIX & $\begin{array}{c}\mathrm{DOC} \\
(\mathrm{mg} / \mathrm{L})\end{array}$ & $\begin{array}{c}\text { SUVA }_{254} \\
\left(\mathbf{L} \cdot \mathbf{m g}^{-1} \cdot \mathbf{m}^{-1}\right)\end{array}$ & FI & BIX & $\mathbf{S}_{\mathbf{R}}$ & $\alpha: \beta$ \\
\hline \multirow{3}{*}{$\begin{array}{l}\text { Phase } \\
1\end{array}$} & LA & $1.07 \pm 0.00$ & $82.61 \pm 5.10$ & $0.04 \pm 0.01$ & $1.06 \pm 0.03$ & $1.00 \pm 0.02$ & $4.53 \pm 0.42$ & $=0.02$ \\
\hline & HA & $1.11 \pm 0.01$ & $92.91 \pm 7.15$ & $0.06 \pm 0.01$ & $1.08 \pm 0.04$ & $1.00 \pm 0.02$ & $4.27 \pm 0.41$ & $1.05 \pm 0.02$ \\
\hline & control & $0.97 \pm 0.01$ & $69.76 \pm 5.73$ & $0.10 \pm 0.02$ & $0.99 \pm 0.04$ & $1.02 \pm 0.03$ & $4.52 \pm 0.78$ & $1.03 \pm 0.02$ \\
\hline \multirow{3}{*}{$\begin{array}{l}\text { Phase } \\
2\end{array}$} & LA & $1.10 \pm 0.00$ & $35.18 \pm 2.13$ & $0.27 \pm 0.03$ & $1.07 \pm 0.02$ & $1.01 \pm 0.05$ & $4.12 \pm 0.41$ & $1.04 \pm 0.03$ \\
\hline & HA & $1.14 \pm 0.01$ & $42.97 \pm 3.79$ & $0.20 \pm 0.03$ & $1.10 \pm 0.01$ & $1.00 \pm 0.03$ & $4.96 \pm 0.35$ & $1.06 \pm 0.04$ \\
\hline & control & $0.98 \pm 0.01$ & $34.20 \pm 2.90$ & $0.30 \pm 0.03$ & $1.01 \pm 0.01$ & $1.01 \pm 0.03$ & $4.18 \pm 0.79$ & $1.04 \pm 0.01$ \\
\hline
\end{tabular}


A qualitative and relative quantification analysis was further carried out for organic carbon products in each group after each phase in terms of their retention times and mass spectra. The main identified organic materials including their relative contents according to the peak area normalization method are compiled in Table 3. A total of 14 compounds were identified, which were ranged from $\mathrm{C} 1$ to $\mathrm{C} 12$. The characterized chemical composition includes some long-chain alkane such as dimethyl decane, some linear, branched, cyclo alkanes (hexane, pentane, methyl cyclohexane), halo hydrocarbons and some aromatic compounds, as well as some small molecule chlorinated compounds such as methylene chloride and Tri-chloromethane. After the experiment in Phase 1, the most abundant products in three groups were identified as n-hexane, especially in control group. Some dimethyl disulfide and trisulfide was only detected with T. tubifex, especially in HA group. As the $\mathrm{C} / \mathrm{N}$ ratio decreased, the chromatographic profiles for the organic compositions after Phase 2 were much simpler and significantly changed than those after Phase 1 , with lower compose of hexane contains and no peaks of benzene compounds, but contained more short-chain organic compounds. The principal constituent in the control group were still identified as hexane products, with a decreased content of n-hexane and an increased content of cyclohexane and dimethyl decane than Phase 1. But under the same consumption dosage of carbon source, branched and cyclic alkanes in control group are insoluble fraction that are more persistent and partially or completely not available for microbial assimilation due to inherent recalcitrance [30], [35], [36]. In T. tubifex added group, the higher carbon source needed for increased $\mathrm{NO}_{3}-\mathrm{N}$ removal in Phase 2 accounted for the less evident of saturated hydrocarbon such as n-hexane and branched alkanes. The methyl acetate, a carboxylic acid derivative and monomers for polyhydroxyalkanoate (PHA), was only detected with T. tubifex in this phase as a biodegradable and energy carbon source [37]. Some sulfur-containing compounds peaks, including dimethyl disulfide and dimethyl trisulfide, were also obviously identified with $T$. tubifex. The abundant content of sulfur compounds was another factor for the enhanced denitrification with $T$. tubifex. The sulphate was also an electron receptor for the anaerobic biodegradation of organic pollutants, and energy source for some chemolithotrophic denitrifiers, which expressed as the followed $\mathrm{NO}_{3}$ $\mathrm{N}+\mathrm{S}+\mathrm{C} \rightarrow \mathrm{N}_{2}+\mathrm{CO}_{2}+\mathrm{S}^{2-}$ [38], [39]. The biodegradation of complicated organic carbon for microbial utilization contains two processes: 1) the complex organic molecules must first be broken down into smaller constituent parts. These monomers, such as organic acids, monosaccharides, alcohols, amino acids, fatty acids and the gases $\mathrm{CO}_{2}$ and $\mathrm{H}_{2}$ are readily available for the microbes. Therefore hydrolysis of these carbon sources is desirable as it will enhance the rate of denitrification [35], [40]. 2) Next, bacteria use oxygen as an electron acceptor to further break down the organic matters into smaller compounds, often producing $\mathrm{CO}_{2}$ as the final product. These primary products were degraded to $\mathrm{CH}_{4}$ and $\mathrm{CO}_{2}$ [14]. In Phase 1, the decomposition of organic carbon by T. tubifex was incomplete. As the increased $\mathrm{NO}_{3}-\mathrm{N}$ and decreased carbon source in Phase 2, the T. tubifex improved the first step in organic carbon degradation process. Most products in LA and HA groups were low-molecular-weight and short-chain aliphatic hydrogencarbon. The majority content of sulfur-containing compounds and fatty acids monomers with T. tubifex were beneficial for microbial utilization. A positive influence of T. tubifex on the biodegradation of organics into bioavailable and biodegradable carbon source was observed [41]. In contrast, the saturated hydrocarbons and branched alkanes were recalcitrant for denitrifiers. 
Table 3. OC compounds identified from the sediment samples by GC-MS analysis.

\begin{tabular}{|c|c|c|c|c|c|c|c|c|c|}
\hline \multirow{2}{*}{\multicolumn{2}{|c|}{ No. Component }} & \multirow{2}{*}{ Group } & \multicolumn{2}{|c|}{ Relative content (\%) } & \multirow{2}{*}{\multicolumn{2}{|c|}{ No. Component }} & \multirow{2}{*}{ Group } & \multicolumn{2}{|c|}{ Relative content (\%) } \\
\hline & & & Phase 1 & Phase 2 & & & & Phase 1 & Phase 2 \\
\hline \multirow{3}{*}{1} & \multirow{3}{*}{$\begin{array}{l}\text { Butane, 2- } \\
\text { methyl- }\end{array}$} & LA & $1.34 \pm 0.25$ & - & \multirow{3}{*}{7} & \multirow{3}{*}{ Cyclohexane } & LA & $1.06 \pm 0.35$ & $55.52 \pm 1.15$ \\
\hline & & HA & $0.72 \pm 0.04$ & - & & & HA & $0.91 \pm 0.13$ & $3.24 \pm 0.80$ \\
\hline & & control & $1.20 \pm 0.44$ & - & & & control & $1.24 \pm 0.83$ & $31.14 \pm 1.08$ \\
\hline \multirow{3}{*}{2} & \multirow{3}{*}{$\begin{array}{l}\text { Methylene } \\
\text { chloride }\end{array}$} & LA & $1.16 \pm 0.03$ & - & \multirow{3}{*}{8} & \multirow{3}{*}{$\begin{array}{l}\text { Disulfide, } \\
\text { dimethyl }\end{array}$} & LA & $2.09 \pm 0.42$ & $251.37 \pm 0.00$ \\
\hline & & HA & $1.24 \pm 0.00$ & - & & & HA & $9.34 \pm 1.21$ & $134.22 \pm 1.32$ \\
\hline & & control & $1.30 \pm 0.33$ & $19.30 \pm 2.47$ & & & control & $0.16 \pm 0.04$ & $4.01 \pm 3.44$ \\
\hline \multirow{3}{*}{3} & \multirow{3}{*}{$\begin{array}{l}\text { Pentane, 3- } \\
\text { methyl- }\end{array}$} & LA & $1.46 \pm 0.22$ & - & \multirow{3}{*}{9} & \multirow{3}{*}{$\begin{array}{l}\text { Benzene } \\
\text { compounds } \\
\text { (except } \\
\text { Toluene) }\end{array}$} & LA & \multicolumn{2}{|c|}{$3.04 \pm 0.05-$} \\
\hline & & HA & $1.53 \pm 0.01$ & - & & & HA & $3.70 \pm 0.38$ & $8-$ \\
\hline & & control & $1.42 \pm 0.13$ & - & & & control & $4.94 \pm 1.14$ & $4-$ \\
\hline \multirow{3}{*}{4} & \multirow{3}{*}{ n-Hexane } & LA & $88.29 \pm 0.52$ & $3.43 \pm 0.18$ & \multirow{3}{*}{10} & \multirow{3}{*}{$\begin{array}{l}\text { Dimethyl } \\
\text { trisulfide }\end{array}$} & LA & $0.25 \pm 0.04$ & $42.83 \pm 0.00$ \\
\hline & & HA & $80.46 \pm 2.68$ & $2.46 \pm 0.38$ & & & HA & $1.13 \pm 0.02$ & $26.43 \pm 0.99$ \\
\hline & & control & $90.25 \pm 1.79$ & 19.87 & & & control & - & - \\
\hline \multirow{3}{*}{5} & \multirow{3}{*}{$\begin{array}{l}\text { Tri- } \\
\text { chloromethane }\end{array}$} & LA & $0.56 \pm 0.11$ & $1.99 \pm 0.06$ & \multirow{3}{*}{11} & \multirow{3}{*}{$\begin{array}{l}\text { Decane, 2,2- } \\
\text { dimethyl- }\end{array}$} & LA & $0.22 \pm 0.03$ & $3.39 \pm 0.00$ \\
\hline & & HA & $0.51 \pm 0.06$ & $0.61 \pm 0.14$ & & & HA & $0.21 \pm 0.04$ & $41.86 \pm 0.24$ \\
\hline & & control & $0.38 \pm 0.00$ & $6.93 \pm 1.17$ & & & control & $0.35 \pm 0.16$ & $611.7 \pm 0.98$ \\
\hline \multirow{3}{*}{6} & \multirow{3}{*}{$\begin{array}{l}\text { Ethane, 1,2- } \\
\text { dichloro- }\end{array}$} & LA & $0.17 \pm 0.05$ & - & \multirow{3}{*}{12} & \multirow{3}{*}{$\begin{array}{l}\text { Acetic acid, } \\
\text { methyl ester }\end{array}$} & LA & - & $40.38 \pm 4.65$ \\
\hline & & HA & $0.21 \pm 0.01$ & - & & & HA & - & $52.13 \pm 4.65$ \\
\hline & & control & $0.23 \pm 0.13$ & - & & & contrc & - & - \\
\hline
\end{tabular}

\subsection{Relationships between microbial community and nutrients removal}

The sediment microbial community composition and species richness in each group were analyzed through targeting the bacterial $16 \mathrm{~S}$ rRNA genes. After quality filtration, $56493 \pm 24,56862 \pm 46$, and $50412 \pm 46$ high-quality reads were obtained in LA, HA and control groups, respectively, indicating increased total number of bacterial quantities with the presence of T. tubifex. The majority of microbes existed in the sediment that related to $\mathrm{N}$ degradation and transformation were also studied. The analyses of specific bacteria contributed to degrade $\mathrm{NO}_{3}-\mathrm{N}$ present in each group were selected and are summarized at phylum level in Fig. 4A, e. g. Pseudomonas (in Proteobacteria), Firmicutes, Bacteroidetes [21], [42], [43]. A strong enrichment of $\mathrm{NO}_{3}-\mathrm{N}-$ degrading bacteria in LA $(67.24 \pm 2.99 \%)$ and HA $(65.39 \pm 3.22 \%)$ groups were observed, which were higher than that in control group (46.26 $4.13 \%)$. The most abundant phylum found with $T$. tubifex, where the greatest $\mathrm{NO}_{3}-\mathrm{N}$ reduction was observed, were tentatively identified as Proteobacteria. Compared to control group, the shift in the dominant groups with T. tubifex has a higher related denitrifiers especially in $\beta$-Proteobacteria and Bacteroidetes. The percentage of 
$\mathrm{NO}_{3}-\mathrm{N}$-degrading bacteria in $T$. tubifex were $9.5 \%$, most of them were Firmicutes and $\gamma$ Proteobacteria. The proportion of autotrophic denitrifiers in sediment were in the order of LA $>$ HA $>$ control, which correspond to $13.6 \pm 2.00 \%, 8.92 \pm 2.17 \%$ and $5.74 \pm 1.28 \%$, respectively, indicating little lower carbon source needed with $T$. tubifex. The nitrification microbes in LA, HA and control group were $61.0 \pm 2.55 \%, 57.1 \pm 1.72 \%$, and $47.5 \pm 5.00 \%$, respectively.

\section{(A)}

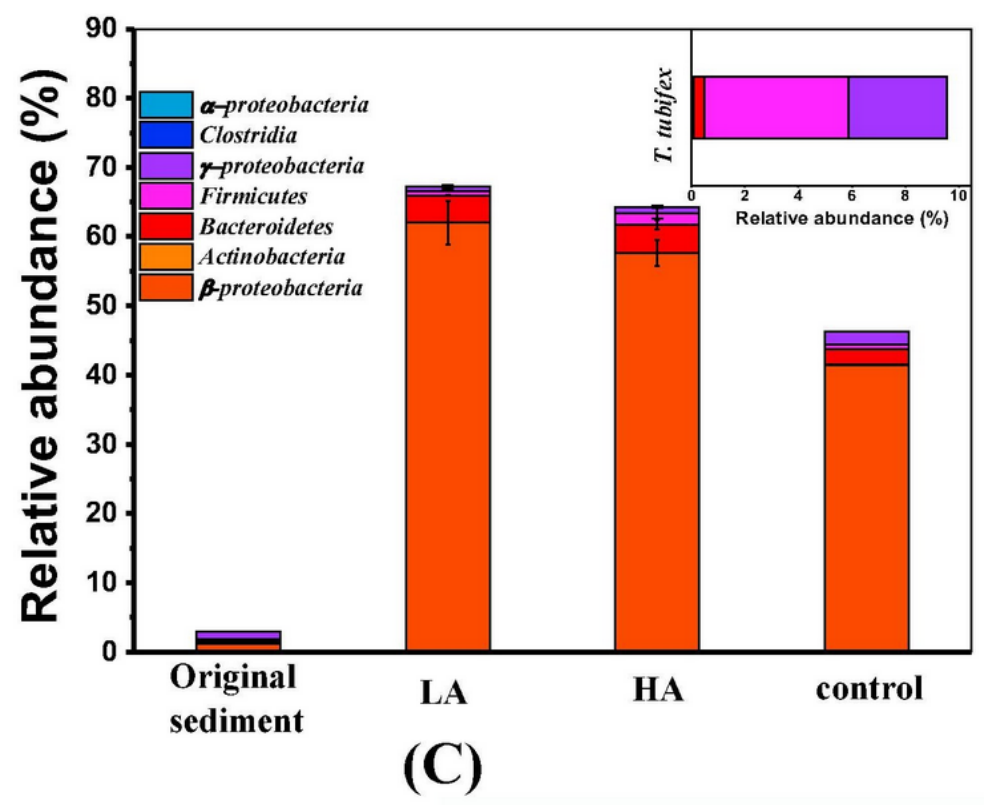

(B)

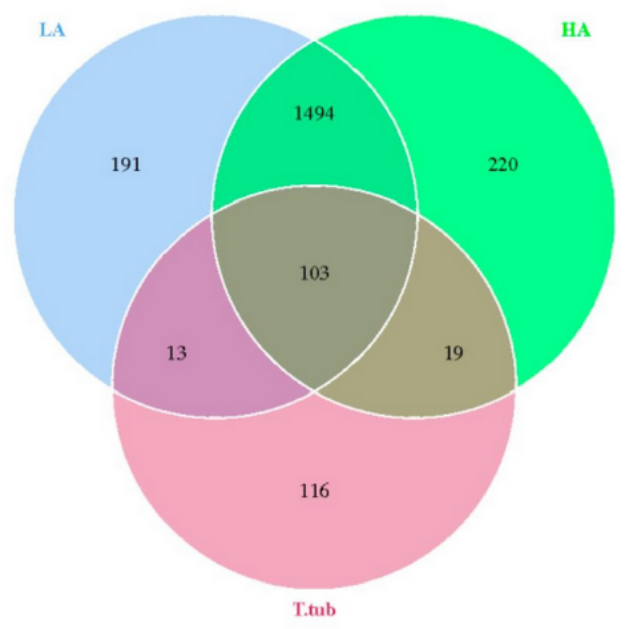

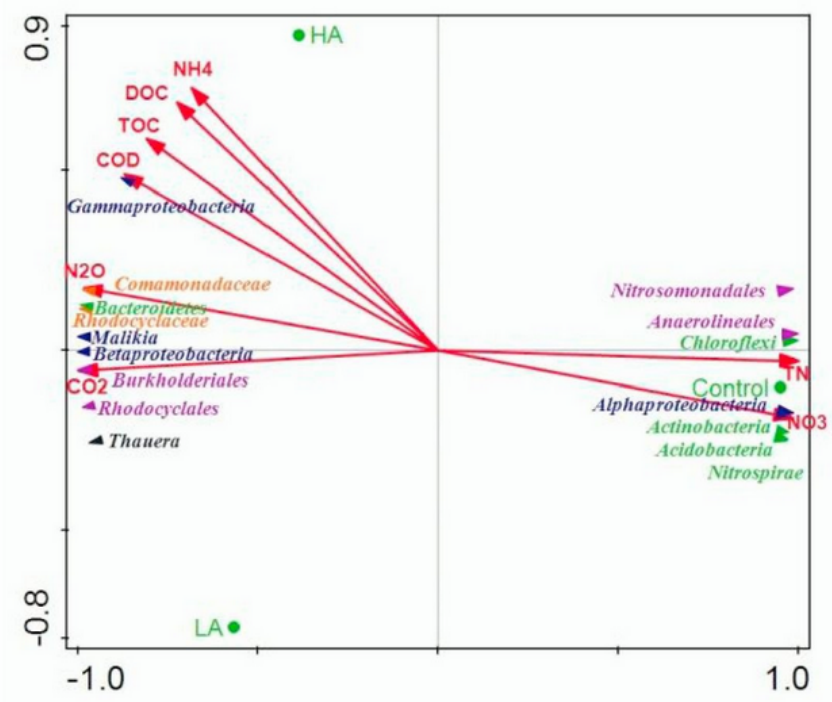

Fig. 4 Taxonomy of 16S rRNA for relative abundance of $\mathrm{NO}_{3}-\mathrm{N}$-degrading microbes summarized at phylum level in each group and T. tubifex (A), and microbial study of Venn diagram for the exclusive and shared OTU in sediment of LA, HA groups and T. tubifex (B). (C) Represented the Principal component analysis (PCA) to investigate the correlation between $\mathrm{N}$ and $\mathrm{C}$ transformation functional genes and treated concentrations of major environment factors. The microbial community with difference in each group were tracked across all samples. Different color means: blue, class; orange, family; green, phylum; purpose, order; black, genus. (For interpretation of the references to colour in this figure legend, the reader is referred to the web version of this article.) 
The certain taxa of C-degrading microorganisms, such as Acinetobacter, Rhodococcus and Arthrobacter (in Actinobacteria), Pseudomonas (in Proteobacteria), Actinobacteria, are key players in organic carbon degradation [21], [44], [45]. In all groups, C-degrading bacteria in $\beta$ Proteobacteria showed a growth, while the functional bacteria in $\alpha$-Proteobacteria and Acidobacteria were decreased than that in original sediment. The C-degrading bacteria in $\beta$ Proteobacteria with T. tubifex was little lower than that of control, but the C-degrading bacteria in $\gamma$-Proteobacteria showed an increase, similar to the C-degrading bacteria detected in T. tubifex. A Venn diagram was constructed to show the common similarity among T. tubifex and sediment in LA and HA groups (Fig. 4B). A great OTUs (1597) were shared between HA and LA groups. LA and HA with T. tubifex also showed higher percentage of shared OTUs, which covered $46.2 \%$ and $48.6 \%$ of the OTUs detected in T. tubifex. The results verified that T. tubifex could enhance the mobility of microorganisms and the assimilation of microbial community to their intestinal microenvironment. In addition, T. tubifex could uptake the microbes in sediment through ingestion and directly regulate microbial population by consuming the large amount of sediment, while the microbes in the digestive system of T. tubifex could also discharge into sediment through faeces. The ecological interactions might thus regulate the microbial community associated with $T$. tubifex and sediment.

PCA analysis clearly indicates the correlations between microbial community structure and major environmental factors (e.g. TOC, $\mathrm{COD}, \mathrm{NO}_{3}-\mathrm{N}$ concentrations) based on taxonomy and abundance (Fig. 4C). The PCA analysis indicated that DOC and TOC concentration had a positive correlation with $\mathrm{NO}_{3}-\mathrm{N}$ removal, it was further verified that the higher denitrification occurred with T. tubifex was partly due to higher organic carbon concentration. Some researchers observed a close relationship between bacterial community composition and nutrient cycling processing, others found inconsistent or weak links [43]. The PC1 and PC2 of maximum variations in the PCA were $96.69 \%$ and $3.31 \%$, indicating the significant interrelations observed among the bacterial community composition and the major environmental factors in each group. A clear distinction of microbial community and nutrient concentration between samples was observed, which indicated the critical microbial community changes with T. tubifex influencing the environmental factors. Previous studies found obvious links between meiofauna and organic carbon decomposition, which is driven by microbial activities [6]. The estimated taxonomy of the functional genes indicated that denitrification was driven by Proteobacteria (phylum), Thauera (genus), Rhodocyclaceae, Burkholderiales (order, in $\beta$-proteobacteria), and related to nir, which was much higher with $T$. tubifex [46]. And the carbon degradation was correlated to Chloroflexi, Acrinobacteria, Acidobaceria (phylum), which was little higher in control group. The difference resulted from the abundance of the $\mathrm{NO}_{3}-\mathrm{N}$-degrading and $\mathrm{C}$-degrading genes potential toward enhanced denitrification and decreased $\mathrm{C}$ consumption with $T$. tubifex. It also reflected that $\mathrm{TN}$ and TOC concentrations in LA group were lower than those in HA group. Thus, lower abundance of $T$. tubifex was more preferable for pollution removal.

\subsection{Proposed pathways of organic carbon transformation and denitrifiers to NO3-N removal with T. tubifex}

The changed microbial community and higher nutrient concentration in sediment with T. tubifex exchange the organic carbon biodegradation and type, which have an impact on microbial $\mathrm{N}$ - 
transformations. Based on the results presented, we derived pathways of organic carbon transformation for denitrifiers and further $\mathrm{NO}_{3}-\mathrm{N}$ removal with T. tubifex addition (Fig. 5). Firstly, the exchange of the sediment microbial community toward the digestive track of T. tubifex can change the $\mathrm{C}$ and $\mathrm{N}$ transformation. T. tubifex transform recalcitrant organics into more biodegradable forms including wide range of short-chain molecule, carboxylic acid derivative, sulfur-containing compounds, and humic-acid organic carbon. The transformed organics have a major impact on the biological activity, abundance and composition of microorganisms in sediment, as they are biodegradable and easy to be utilized by microorganisms [47]. The by-products of biodegraded organics can also be used as an external carbon source for denitrification thus allowing microorganisms to mineralize the residuals [40]. Correspondingly, anaerobic microorganisms can use available substances such as $\mathrm{NO}_{3}-\mathrm{N}$, and $\mathrm{CO}_{2}$ as their electron acceptors to break down organic compounds into smaller constituents, and producing $\mathrm{CO}_{2}$ as the final products [20]. Secondly, the large increase in organic carbon concentration with T. tubifex received from the deposition, as well as biodegradation and transit of carbon source, increase the available $\mathrm{C}$ in the sediment.

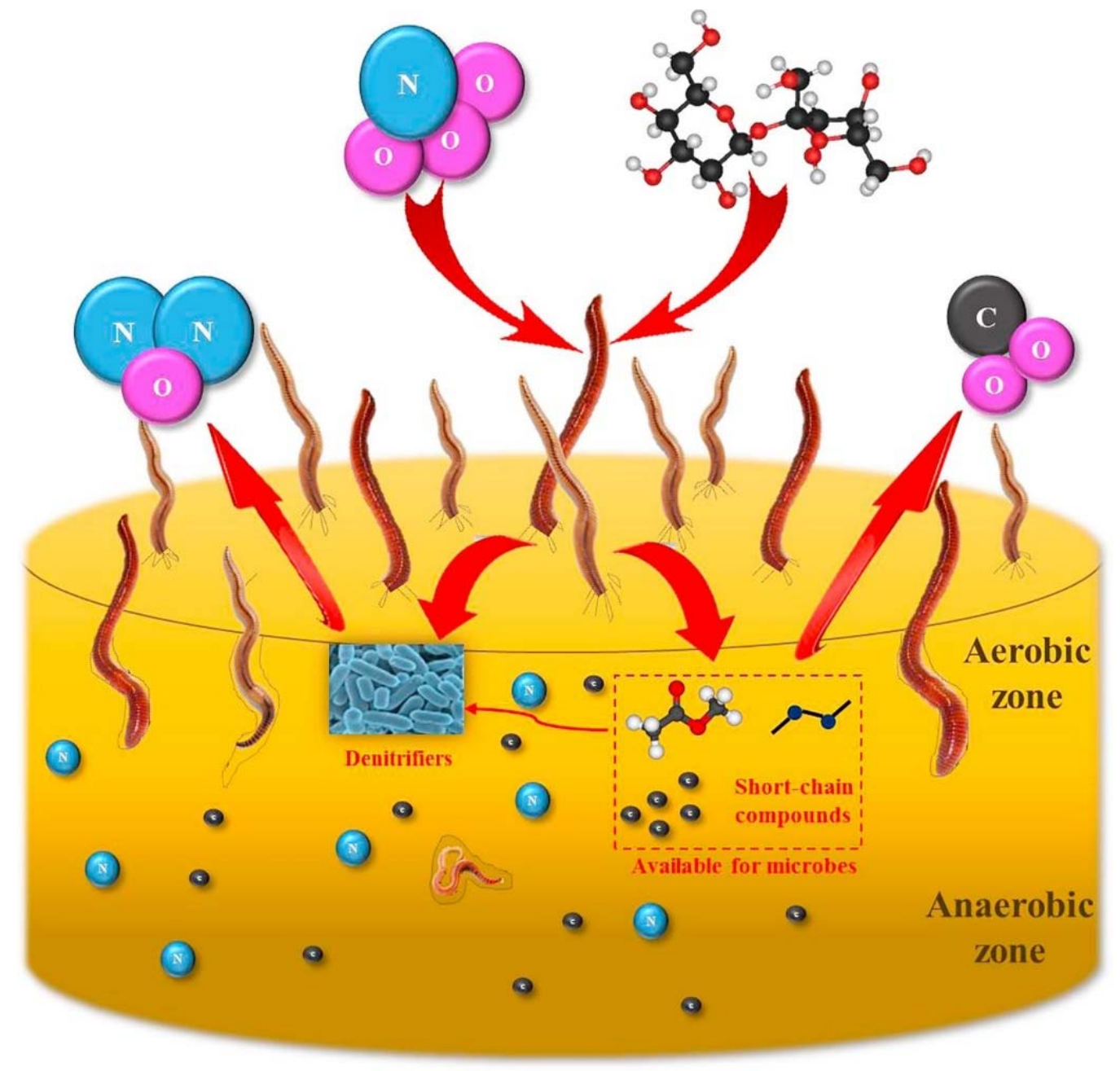

Fig. 5 Conceptual model for the proposed mechanism of organic carbon characteristics and denitrifiers for $\mathrm{NO}_{3}-\mathrm{N}$ removal with $T$. tubifex addition.

The changed trophic status in sediment with T. tubifex are beneficial for the degradation of saturated and unsaturated aliphatic and aromatic organics [36]. In most cases, a positive influence of nutrients 
on the acceleration of soil humication and biodegradation of hydrocarbons extents has been observed [32]. Moreover, PCA analysis also confirmed that $\mathrm{NO}_{3}-\mathrm{N}$ removal was highly correlated with $\mathrm{C}$ transformation and microbial community changed with T. tubifex in our study. Thus, $T$. tubifex demonstrated better strategy for hydrocarbon degradation to generate partially bioavailable organic carbon that can be readily utilized by denitrifiers. The research provides effective values for the scope of biological wastewater treatment. The organic carbon migration with T. tubifex in aquatic environment will be deeply elucidated in our further study.

\section{Conclusions}

This is the first study to deeply analysis the organic carbon degradation, as well as the relationships between organic carbon forms and related microbes toward $\mathrm{NO}_{3}-\mathrm{N}$ removal with $T$. tubifex under different $\mathrm{NO}_{3}-\mathrm{N}$ concentrations and $\mathrm{C} / \mathrm{N}$ ratios. The $\mathrm{NO}_{3}-\mathrm{N}$ removal efficiency was threefold enhanced with T. bufifex while 5.10-11.20\% lower TOC was consumed. T. tubifex transformed the carbon source into DOC and short-chain compounds. As the initial $\mathrm{NO}_{3}-\mathrm{N}$ concentration increased and $\mathrm{C} / \mathrm{N}$ ratio decreased, the carbon source could further transformed to methyl acetate, sulfurcontaining and humic-like compounds, which could be utilized by denitrifiers directly. The changed organic carbon transformation with T. tubifex was mainly attributed to the higher nutrient contents and changed microbial community in sediment. The changed trophic status and related microbial abundance in sediment with T. tubifex contributed to the degradation of saturated and unsaturated aliphatic and aromatic organics. T. tubifex could influence the microbial community through their intestinal microenvironment and activity. The proportions of denitrifiers with $T$. tubifex were $21 \%$ higher compared to control group. The nature of organics and denitrifiers were important factors for excellent $\mathrm{NO}_{3}-\mathrm{N}$ removal with $T$. tubifex.

\section{Acknowledgements}

This research was supported by the International Cooperation Project (No. 51720105013), the China Major Science and Technology Program for Water Pollution Control and Treatment (No. 2017ZX07101003) and the National Natural Science Foundation of China (No. 51720105013).

\section{References}

[1] J.T. Scott, M.J. McCarthy, W.S. Gardner, R.D. Doyle, Denitrification, dissimilatory nitrate reduction to ammonium, and nitrogen fixation along a nitrate concentration gradient in a created freshwater wetland, Biogeochemistry 87 (2008) 99-111.

[2] K.L. Kuntz, Biodiversity and the role of bioturbating invertebrates in nutrient cycling in stormwater ponds, 2015.

[3] Y. Kang, J. Zhang, H. Xie, Z. Guo, P. Li, C. Cheng, L. Lv, Enhancement of the performance of constructed wetlands for wastewater treatment in winter: the effect of Tubifex tubifex, RSC Adv. 6 (2016) 34841-34848.

[4] Y. Kang, J. Zhang, H. Xie, Z. Guo, H.H. Ngo, W. Guo, S. Liang, Enhanced nutrient removal and mechanisms study in benthic fauna added surface-flow constructed wetlands: the role of Tubifex tubifex, Bioresour. Technol. 224 (2017) 157-165.

[5] S. Bonaglia, F.A. Nascimento, M. Bartoli, I. Klawonn, V. Brüchert, Meiofauna increases bacterial denitrification in marine sediments, Nat. Commun. 5 (2014). 
[6] F.J. Nascimento, J. Näslund, R. Elmgren, Meiofauna enhances organic matter mineralization in soft sediment ecosystems, Limnol. Oceanogr. 57 (2012) 338-346.

[7] W. Zhi, L. Yuan, G. Ji, C. He, Enhanced long-term nitrogen removal and its quantitative molecular mechanism in tidal flow constructed wetlands, Environ. Sci. Technol. 49 (2015) 4575-4583.

[8] D.V. Erler, B.D. Eyre, L. Davison, The contribution of anammox and denitrification to sediment N2 production in a surface flow constructed wetland, Environ. Sci. Technol. 42 (2008) 9144 9150.

[9] L. Cao, W. Sun, Y. Zhang, S. Feng, J. Dong, Y. Zhang, B.E. Rittmann, Competition for electrons between reductive dechlorination and denitrification, Front. Environ. Sci. Eng. 11 (2017) 14.

[10] X. Zhou, L. Jia, C. Liang, L. Feng, R. Wang, H. Wu, Simultaneous enhancement of nitrogen removal and nitrous oxide reduction by a saturated biochar-based intermittent aeration vertical flow constructed wetland: effects of influent strength, Chem. Eng. J. 334 (2017) 1842-1850.

[11] G. Luo, L. Li, Q. Liu, G. Xu, H. Tan, Effect of dissolved oxygen on heterotrophic denitrification using poly (butylene succinate) as the carbon source and biofilm carrier, Bioresour. Technol. 171 (2014) 152-158.

[12] W. Xing, D. Li, J. Li, Q. Hu, S. Deng, Nitrate removal and microbial analysis by combined micro-electrolysis and autotrophic denitrification, Bioresour. Technol. 211 (2016) 240-247.

[13] P. Li, J. Zuo, Y. Wang, J. Zhao, L. Tang, Z. Li, Tertiary nitrogen removal for municipal wastewater using a solid-phase denitrifying biofilter with polycaprolactone as the carbon source and filtration medium, Water Res. 93 (2016) 74-83.

[14] P. Meng, H. Pei, W. Hu, Y. Shao, Z. Li, How to increase microbial degradation in constructed wetlands: influencing factors and improvement measures, Bioresour. Technol. 157 (2014) 316-326.

[15] Z. Shen, Y. Zhou, J. Wang, Comparison of denitrification performance and microbial diversity using starch/polylactic acid blends and ethanol as electron donor for nitrate removal, Bioresour. Technol. 131 (2013) 33-39.

[16] T.-C. Lin, P.-T. Pan, S.-S. Cheng, Ex situ bioremediation of oil-contaminated soil, J. Hazard. Mater. 176 (2010) 27-34.

[17] X. Zhu, M. Burger, T.A. Doane, W.R. Horwath, Ammonia oxidation pathways and nitrifier denitrification are significant sources of $\mathrm{N} 2 \mathrm{O}$ and $\mathrm{NO}$ under low oxygen availability, Proc. Natl. Acad. Sci. 110 (2013) 6328-6333.

[18] D.L. Stoliker, D.A. Repert, R.L. Smith, B. Song, D.R. LeBlanc, T.D. McCobb, C.H. Conaway, S.P. Hyun, D.-C. Koh, H.S. Moon, Hydrologic controls on nitrogen cycling processes and functional gene abundance in sediments of a groundwater flow-through lake, Environ. Sci. Technol. 50 (2016) 3649-3657.

[19] P. Haapea, T. Tuhkanen, Integrated treatment of PAH contaminated soil by soil washing, ozonation and biological treatment, J. Hazard. Mater. 136 (2006) 244-250.

[20] S. Gan, E. Lau, H. Ng, Remediation of soils contaminated with polycyclic aromatic hydrocarbons (PAHs), J. Hazard. Mater. 172 (2009) 532-549. 
[21] W.A. Overholt, K.P. Marks, I.C. Romero, D.J. Hollander, T.W. Snell, J.E. Kostka, Hydrocarbon-degrading bacteria exhibit a species-specific response to dispersed oil while moderating ecotoxicity, Appl. Environ. Microb. 82 (2016) 518-527.

[22] Y. Liu, C. Liu, W.C. Nelson, L. Shi, F. Xu, Y. Liu, A. Yan, L. Zhong, C. Thompson, J.K. Fredrickson, Effect of water chemistry and hydrodynamics on nitrogen transformation activity and microbial community functional potential in hyporheic zone sediment columns, Environ. Sci. Technol. 51 (2017) 4877-4886.

[23] J. Fan, J. Zhang, W. Guo, S. Liang, H. Wu, Enhanced long-term organics and nitrogen removal and associated microbial community in intermittently aerated subsurface flow constructed wetlands, Bioresour. Technol. 214 (2016) 871-875.

[24] Y. Zou, Z. Hu, J. Zhang, H. Xie, C. Guimbaud, Y. Fang, Effects of pH on nitrogen transformations in media-based aquaponics, Bioresour. Technol. 210 (2016) 81-87.

[25] APHA, Standard Methods for the Examination of Water and Wastewater, 21st ed., American Public Health Association/American Water Works Association/Water Environment Federation, Washington, DC, USA, 2005.

[26] W. Chen, P. Westerhoff, J.A. Leenheer, K. Booksh, Fluorescence excitation-emission matrix regional integration to quantify spectra for dissolved organic matter, Environ. Sci. Technol. 37 (2003) 5701-5710.

[27] P. Li, Y. Wang, J. Zuo, R. Wang, J. Zhao, Y. Du, Nitrogen removal and N2O accumulation during hydrogenotrophic denitrification: influence of environmental factors and microbial community characteristics, Environ. Sci. Technol. 51 (2016) 870-879.

[28] A.H. Magill, J.D. Aber, Dissolved organic carbon and nitrogen relationships in forest litter as affected by nitrogen deposition, Soil Biol. Biochem. 32 (2000) 603-613.

[29] C. Anderson, M. Peterson, D. Curtin, Base cations, K+ and Ca 2+, have contrasting effects on soil carbon, nitrogen and denitrification dynamics as $\mathrm{pH}$ rises, Soil Biol. Biochem. 113 (2017) 99-107.

[30] T. Chen, A.G. Delgado, B.M. Yavuz, J. Maldonado, Y. Zuo, R. Kamath, P. Westerhoff, R. Krajmalnik-Brown, B.E. Rittmann, Interpreting interactions between ozone and residual petroleum hydrocarbons in soil, Environ. Sci. Technol. 51 (2016) 506-513.

[31] K. Šmídová, J. Hofman, Uptake kinetics of five hydrophobic organic pollutants in the earthworm Eisenia fetida in six different soils, J. Hazard. Mater. 267 (2014) 175-182.

[32] J. Rodriguez-Campos, L. Dendooven, D. Alvarez-Bernal, S.M. Contreras-Ramos, Potential of earthworms to accelerate removal of organic contaminants from soil: a review, Appl. Soil Ecol. 79 (2014) 10-25.

[33] T. Chen, A.G. Delgado, B.M. Yavuz, A.J. Proctor, J. Maldonado, Y. Zuo, P. Westerhoff, R. Krajmalnik-Brown, B.E. Rittmann, Ozone enhances biodegradability of heavy hydrocarbons in soil, J. Environ. Eng. Sci. 11 (2016) 7-17.

[34] S.K. Ishii, T.H. Boyer, Behavior of reoccurring PARAFAC components in fluorescent dissolved organic matter in natural and engineered systems: a critical review, Environ. Sci. Technol. 46 (2012) 2006-2017. 
[35] F. Liu, Y. Tian, Y. Ding, Z. Li, The use of fermentation liquid of wastewater primary sedimentation sludge as supplemental carbon source for denitrification based on enhanced anaerobic fermentation, Bioresour. Technol. 219 (2016) 6-13.

[36] C. Chaineau, G. Rougeux, C. Yepremian, J. Oudot, Effects of nutrient concentration on the biodegradation of crude oil and associated microbial populations in the soil, Soil Biol. Biochem. 37 (2005) 1490-1497.

[37] Q. Tian, L. Zhuang, S.K. Ong, Q. Wang, K. Wang, X. Xie, Y. Zhu, F. Li, Phosphorus (P) recovery coupled with increasing influent ammonium facilitated intracellular carbon source storage and simultaneous aerobic phosphorus \& nitrogen removal, Water Res. 119 (2017) 267275.

[38] D.Y. Huang, S.G. Zhou, Q. Chen, B. Zhao, Y. Yuan, Z. Li, Enhanced anaerobic degradation of organic pollutants in a soil microbial fuel cell, Chem. Eng. J. 172 (2011) 647-653.

[39] W. Yang, H. Lu, S.K. Khanal, Q. Zhao, L. Meng, G.H. Chen, Granulation of sulfuroxidizing bacteria for autotrophic denitrification, Water Res. 104 (2016) 507.

[40] P.B. Dhamole, S. D'Souza, S. Lele, A review on alternative carbon sources for biological treatment of nitrate waste, J. Inst. Eng. (India): Ser. E 96 (2015) 63-73.

[41] T. Onodera, S. Sase, P. Choeisai, W. Yoochatchaval, H. Sumino, T. Yamaguchi, Y. Ebie, K. $\mathrm{Xu}, \mathrm{N}$. Tomioka, M. Mizuochi, Development of a treatment system for molasses wastewater: the effects of cation inhibition on the anaerobic degradation process, Bioresour. Technol. 131 (2013) 295-302.

[42] P. Wunderlin, J. Mohn, A. Joss, L. Emmenegger, H. Siegrist, Mechanisms of $\mathrm{N}_{2} \mathrm{O}$ production in biological wastewater treatment under nitrifying and denitrifying conditions, Water Res. 46 (2012) 1027-1037.

[43] X. Shi, K.K. Ng, X.-R. Li, H.Y. Ng, Investigation of intertidal wetland sediment as a novel inoculation source for anaerobic saline wastewater treatment, Environ. Sci. Technol. 49 (2015) 6231-6239.

[44] S. Banerjee, C.A. Kirkby, D. Schmutter, A. Bissett, J.A. Kirkegaard, A.E. Richardson, Network analysis reveals functional redundancy and keystone taxa amongst bacterial and fungal communities during organic matter decomposition in an arable soil, Soil Biol. Biochem. 97 (2016) 188-198.

[45] J.C. Stegen, J.K. Fredrickson, M.J. Wilkins, A.E. Konopka, W.C. Nelson, E.V. Arntzen, W.B. Chrisler, R.K. Chu, R.E. Danczak, S.J. Fansler, Groundwater-surface water mixing shifts ecological assembly processes and stimulates organic carbon turnover, Nat. Commun. 7 (2016).

[46] Q. Kong, J. Zhang, M. Miao, L. Tian, N. Guo, S. Liang, Partial nitrification and nitrous oxide emission in an intermittently aerated sequencing batch biofilm reactor, Chem. Eng. J. 217 (2013) 435-441.

[47] T.L. Swenson, S. Jenkins, B.P. Bowen, T.R. Northen, Untargeted soil metabolomics methods for analysis of extractable organic matter, Soil Biol. Biochem. 80 (2015) 189-198. 